\title{
Using of citrus by-products in farm animals feeding
}

\begin{abstract}
Conventional feedstuffs are often expensive and therefore the utilization of agroindustrial by-products as feedstuffs may be economically worthwhile. Ruminant feeding systems based on locally available by-product feedstuffs (BPF) are often a practical alternative because the rumen microbial ecosystem can utilize BPF which often contain high levels of structural fiber to meet their nutrient requirements for maintenance, growth, reproduction and production. Citrus by-product includes numerous BPF which varies according to the originating crop and method of production that is an important component of ruminant feeding systems in many areas of the world. Citrus pulp is the residues of citrus juice canning industry. Oranges, tangerines, lemons or grapefruits are used for this purpose but the common raw material for juice industry elsewhere in the world is orange fruit (Citrus sinensis). Citrus pulp is the solid residue that remains after fresh fruits are squeezed into juice. Citrus Pulp is the dried residue of peel, pulp and seeds of oranges, grapefruit and other citrus fruit.

The nutritional value of citrus pulp is high owing to its high content of readily fermentable carbohydrates and contains a variety of energy substrates for ruminal microbes, including both soluble carbohydrates and a readily digestible neutral detergent fiber (NDF) fraction. Therefore, when citrus BPF substituted for starchy feeds, NDF and acid detergent fiber (ADF) digestibility coefficients are increased. Dried citrus pulp is also a valuable feed for beef and growing cattle and can partly replace energy sources safely included in rations at $20-30 \%$ of the DM possible to include up to $40 \%$ dried citrus pulp in the diets of fattening cattle without altering animal health. To increase the usefulness of citrus pulp it can be preserved by drying which can been used as the main energy source for beef cattle and heifers up to $45 \%$ has been used in calf rations but should not be used at high levels for milking cows as milk production tends to decrease. In addition, the liquid obtained from pressing citrus waste with 9 to 15 percent soluble solids, of which 60 to 75 percent are sugars can be concentrated to become citrus molasses.
\end{abstract}

Keywords: citrus by-product, feedstuffs, ruminants, growth, milk yield, body functions
Volume I Issue 3 - 2017

\author{
Alsaied Alnaimy, AE Gad, MM Mustafa, MAA \\ Atta, HAM Basuony \\ Department of Biological Applications, Nuclear Research \\ Center, Egypt
}

Correspondence: Alsaied Alnaimy, Department of Biological Applications, Radioisotopes Applications Division, Nuclear Research Center, Egypt, Email alnaimy2520I I@gmail.com

Received: July 22, 2017 | Published: September 15, 2017
Abbreviations: TDN, tons of total digestible nutrients; AIBP, agro industrial by products; ADF, acid detergent fiber; NDF, neutral detergent fiber

\section{Introduction}

About 13.0million tons of total digestible nutrients (TDN) are required per year in Egypt; only 9.6 million tons are annually produced providing $75 \%$ of the livestock energy requirements. Shortage in animal feeds has been found to have a negative impact on the development of animal production in Egypt. Nontraditional feed resources such as crop residues and agro-industrial by-products must searched in order to decrease the relay on traditional resources to fill the gap and to decrease feeding costs. ${ }^{2}$ The relatively high prices of concentrates and its ingredients in Egypt are the major problem in animal production. At the same time, increase wastes products from feed industry at wastes in human, such as citrus pulp, pea pods and tomato pulp, potato wastes obtained from many company feed industry such as, Kaha, Montana and many company in $10^{\text {th }}$ Ramadan, El-Sadat and 6th October Cities. ${ }^{3}$

The annually local production of these products estimated to be 4.0million tons containing 1.9 million tons wastes containing 747 megatons and 88 megatons of TDN and CP, respectively. ${ }^{4}$ This amount and others of the agro-industrial by products could participate in covering the nutritional gab found in animal feeds and avoiding the competition between human and animal in edible grains consumption. Citrus (Citrus spp) is one of the most important fruits crop worldwide. In 2010 , oranges accounted for $61 \%$ of the world citrus production ( 82 million Ton). About $30 \%$ of the production of citrus fruits (and $40 \%$ of orange production) is processed, principally to make juice, and results large quantities of by-products. ${ }^{5} \mathrm{~A}$ brief description of the potential use of citrus industrial by product in livestock feeding is discussed in this review. In addition, the outline on citrus by-products in ruminant feeding are reviewed in this paper. This review evaluates citrus by-products wastes in regard to their nutrient composition, nutrient digestion and ruminal fermentation and their impact on animal performance.

\section{Using citrus by-products in farm animals feeding}

Importance of citrus by-products in ruminants feeding: His utilization of agro-industrial by-products may be economically worthwhile, since conventional feedstuffs are often expensive. Ruminant feeding systems based on locally available by-product feedstuffs (BPF) are often a practical alternative because the rumen microbial ecosystem can utilize BPF which often contain high levels of structural fiber to meet their nutrient requirements for maintenance, growth, reproduction and production. ${ }^{6}$ Citrus by-products are utilized as a low cost nutritional supplement to the diets of cattle 
and have been suggested to inhibit the growth of both Escherichia coli and Salmonella within mixed ruminal microorganism fluid media when supplemented with citrus by-products. ${ }^{7}$ Increased disposal costs in many parts of the world have increased interest in utilization of citrus BPF as alternative feeds for ruminants. The main citrus BPF fed to ruminants are fresh citrus pulp, citrus silage, dried citrus pulp, citrus meal and fines, citrus molasses, citrus peel liquor and citrus activated sludge. Other minor BPF from citrus include cull or excess fruit. Citrus BPF can be used as a high energy feed in ruminant rations to support growth and lactation with fewer negative effects on rumen fermentation than starch rich feeds ${ }^{8}$ (Figure 1).

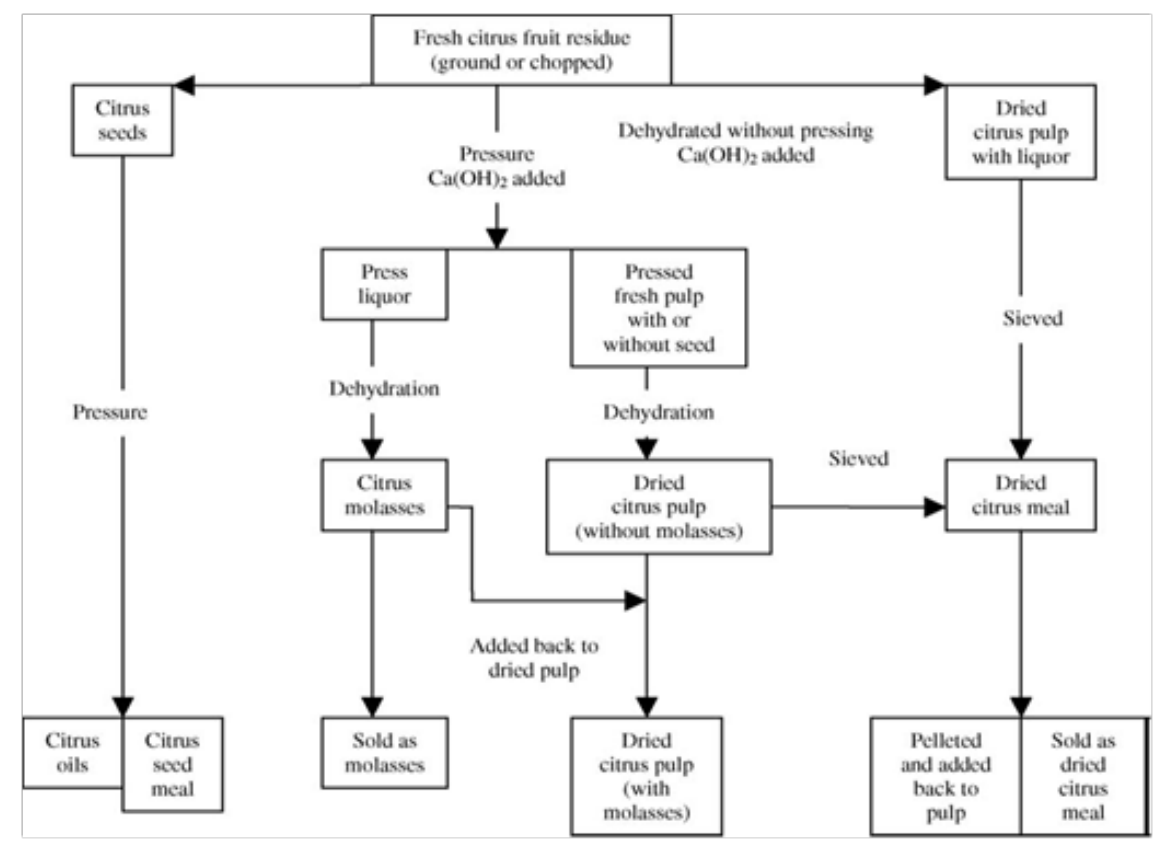

Figure I Schematic presentation of citrus by-product production Sinclair. ${ }^{43}$

Main constraints in using agro-industrial by products in anima feeding: Agro-industrial by products (AIBP) refers to the by-products derived in the industry due to processing of main products. By products are less fibrous, more concentrated, highly nutritious and less costly as compared to crop residues. ${ }^{9}$ Main constraints on use of some feed resources may account for the limited use of several AIBPs. The main constraints are listed below:

i. Agro-industrial by products is often variable in composition

ii. Short period of utilization i.e. seasonal availability and local production

iii. High moisture content.

iv. High cost of handling and transportation from the production site to the farm.

v. Farmers are not aware of the nutritive value of some feed sources.

vi. Competition with alternative users.

vii. Presence of anti-nutritional factors.

viii. Dehydration may cause loss of protein value.

ix. Lipid rancidity of high fat products in olive cake.

x. Mould growth (aflatoxins) may cause toxicity.

Moreover, the difficulty of the use of these by-product as fresh material for extended periods and the lack of efficient ways for their integration in feeding calendars may account for their under utilization
Production of citrus by-products: Citrus pulp is the residues of citrus juice canning industry. Oranges, tangerines, lemons or grapefruits are used for this purpose. The common raw material for juice industry, particularly in countries not only around the Mediterranean basin but also elsewhere in the world is orange fruit (Citrus sinensis). Total world citrus production averaged 69.4million tons per year from 2000 through 2003 , inclusive. About $24 \%$ of world production of citrus is in the Mediterranean countries of Spain, Italy, Greece, Egypt, Turkey and Morocco with Brazil (24\%) being major individual citrus producing countries. $^{5}$ The genus Citrus includes several important fruits with the most important one worldwide basis being sweet orange $(67.8 \%$ of world citrus production; $17.9 \%$ tangerine; $6.3 \%$ lemon; and $5.0 \%$ grapefruit). ${ }^{5}$ Citrus fruits are principally consumed by humans as fresh fruit or processed juice, either fresh chilled or concentrated. After juice is extracted from the fruit, there remains a residue comprised of peel, pulp, rag and seeds. These components either individually or in various combinations are the source materials from which citrus BPF are produced.

The main citrus BPF from citrus processing are fresh $\mathrm{CP}$ which is the whole residue after extraction of juice, representing between 492 and $692 \mathrm{~g} / \mathrm{kg}$ of fresh citrus fruit with $600-650 \mathrm{~g} \mathrm{DM} / \mathrm{kg}$ peel, $300-350 \mathrm{~g} / \mathrm{kg}$ pulp and $0-100 \mathrm{~g} / \mathrm{kg}$ seeds and DCP which is formed by shedding, liming, pressing and drying the peel, pulp and seed residues to about $80 \mathrm{~g} / \mathrm{kg}$ moisture and citrus meal and fines which is formed and separated during the drying process. ${ }^{10}$ Citrus pulp consisting of a mixture of peels, inside portions, seeds and culled fruit which represent approximately $50-65 \%$ of the whole fruit weight depending on the variety of fruit, the processing methods and environmental factors. ${ }^{11}$ 
Dried citrus pulp: To increase the usefulness of citrus pulp it can be preserved by drying, but direct drying is difficult because of the slimy consistency of the waste. The hydrophilic nature of the pectin in the waste can be destroyed by adding lime and the machinery for drying is expensive and the process is economical only where large amounts of waste accumulate. The first step in the drying process is addition of $0.5 \%$ lime to the shredded skins to neutralize the free acids and to bind the fruit pectin. ${ }^{12}$ Dried citrus pulp that has been pressed before drying is somewhat lower in nitrogen-free extract. Only the contents of ash, fiber and water are consistent, while protein, fat and nitrogen-free extract vary according to season, the proportions of oranges and grapefruit used and also the quantity of seeds in the fruits (Table 1). Citrus pulp is the most versatile of the citrus feeds; it is palatable, rich in nutrients, easily mixed with other feed ingredients and exerts a mildly laxative effect. It can be stored for all-year feeding and deteriorates less in storage than many other feeds. DCP is slightly hygroscopic and should therefore be stored in as dry a place as possible. Dried CP has been used as the main energy source for beef cattle and heifers, and up to $45 \%$ has been used in calf rations. The pulp should not be used at high levels for milking cows as milk production tends to decrease. Digestibility trials with sheep show that its digestibility decreases when $\mathrm{CP}$ is included at levels in excess of $30 \%$ of the ration ${ }^{13}$ (Figures 2-4).

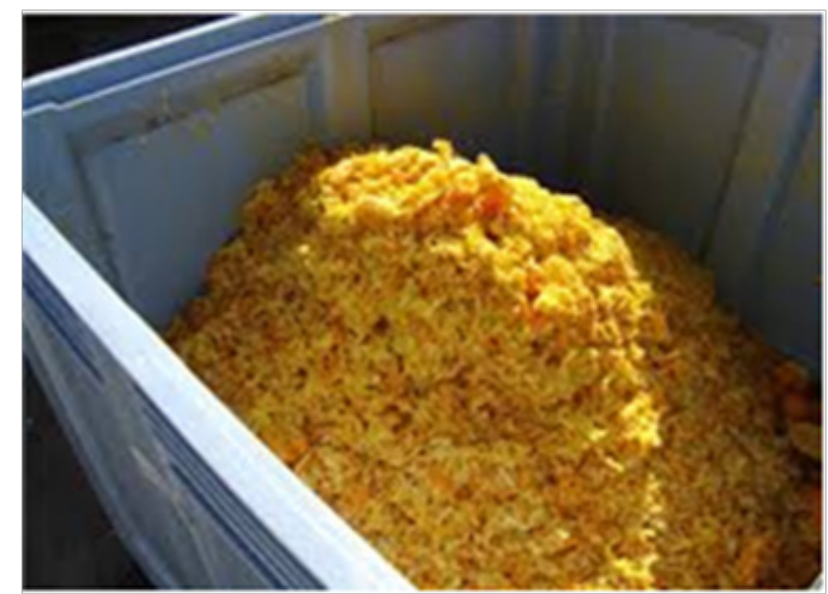

Figure 2 Citrus pulp wastes.

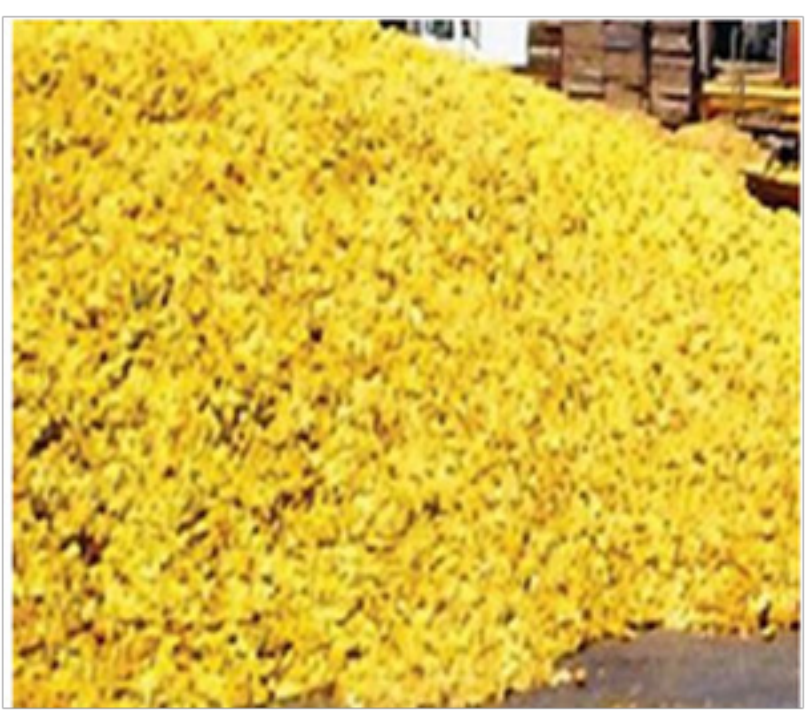

Figure 3 Citrus orange wastes.

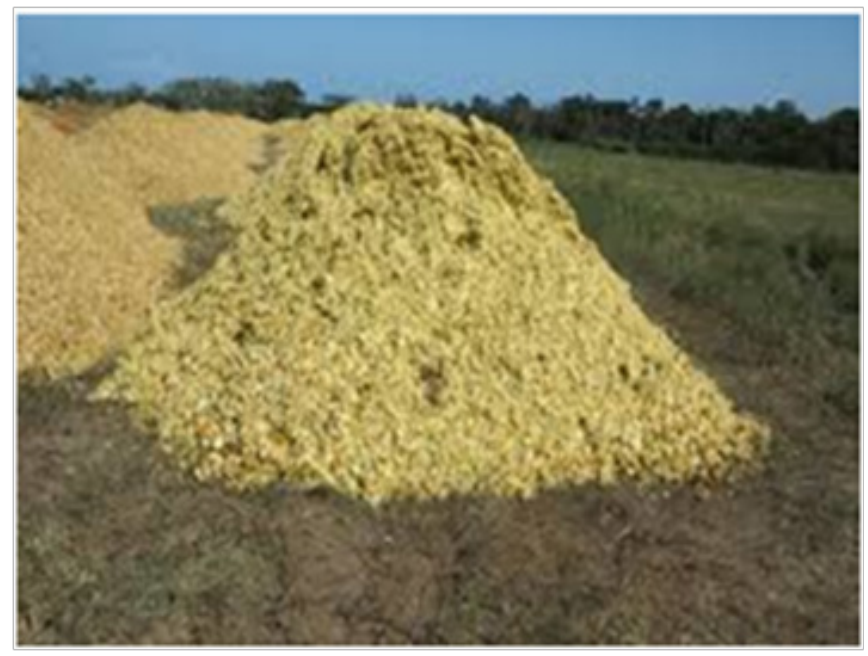

Figure 4 Fresh Citrus Pulp Industry.

Table I Dried citrus pulp (DCP) composition. ${ }^{12}$

\begin{tabular}{lll}
\hline Dried citrus pulp & Range & Average \\
\hline Protein \% & $5.0-9.3$ & 6.16 \\
Fat \% & $1.3-9.1$ & 3.74 \\
Crude Fiber \% & $6.4-16.8$ & 12.28 \\
Ash \% & $3.1-8.4$ & 4.68 \\
Moisture \% & $3.5-13.7$ & 8.58
\end{tabular}

Citrus molasses: The liquid obtained from pressing citrus waste with 9 to $15 \%$ soluble solids, of which 60 to $75 \%$ are sugars can be concentrated to become citrus molasses. Without this further processing the liquor has a high biological oxygen demand and can create a waste problem if dumped into lakes or streams. It may indeed amount to more than half of the total weight of the waste. Citrus molasses is normally a thick viscous liquid which is dark brown to almost black in color and has a very bitter taste. This taste does not affect its usefulness in cattle feeding, however, and in fact it can be used in the same way as, sugarcane molasses. It may be mixed with pressed pulp prior to drying and thus the energy content is increased in the dried product without destroying the keeping quality of the pulp and when fed free choice to cattle up to $3 \mathrm{~kg}$ per day are consumed. ${ }^{14}$ By-products from the citrus industry can make an important addition to the amount of locally produced feed for animals. In countries where the quantity of peel and rag from canning industries is large, drying is in most cases the preferred way of conservation because DCP is easy to handle, to transport and to mix into compound feeds. Close to 700 000 tons of such DCP are produced yearly in the United States. The cost of drying can be estimated at about US $\$ 40$ per ton of the dry meal (10\% moisture) (Figures 5-8). ${ }^{15}$

Citrus pulp description: Citrus pulp is the solid residue that remains after fresh fruits are squeezed into juice. CP is the dried residue of peel, pulp and seeds of oranges, grapefruit and other citrus fruit. It amounts to $50-70 \%$ of the fresh weight of the original fruit and contains the peel (60-65\%), internal tissues (30-35\%) and seeds $(0-10 \%) .{ }^{16} \mathrm{CP}$ is usually made from oranges but may also contain by-products of other citrus fruits, notably grapefruits and lemons. Fresh citrus pulp has a natural acidity but it still is a perishable product due to its high content 
of water and soluble sugars and may quickly sour, ferment and release sludge hazardous to the environment. ${ }^{16}$ Dried or pelleted CP is one of the most desirable energy feeds and can be considered in feeding programs as being; a dry carbohydrate concentrate with high TDN content averaging about $74 \%$; a bulk energy feed with a high degree of water absorption and having above-average palatability for cattle. As a general rule, $40-45 \%$ of the ground snapped corn in a dairy ration can be replaced by DCP or pellets. ${ }^{12}$

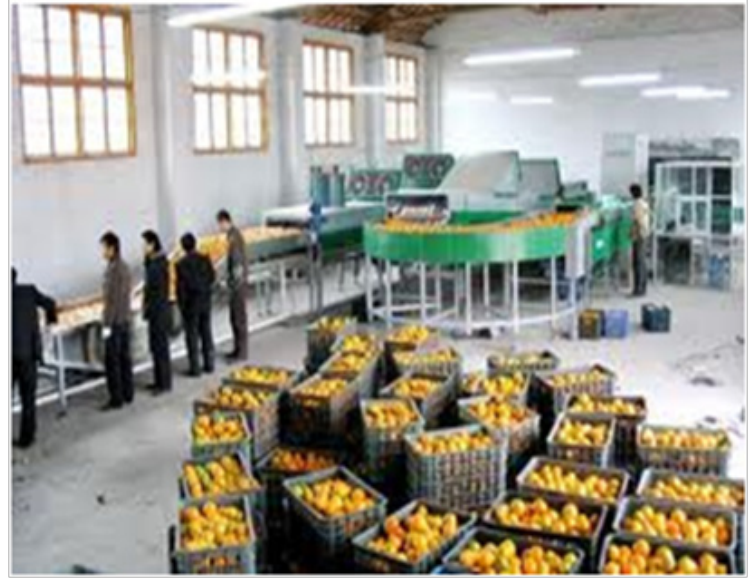

Figure $\mathbf{5}$ Citrus orange as fruits wastes in the airport.

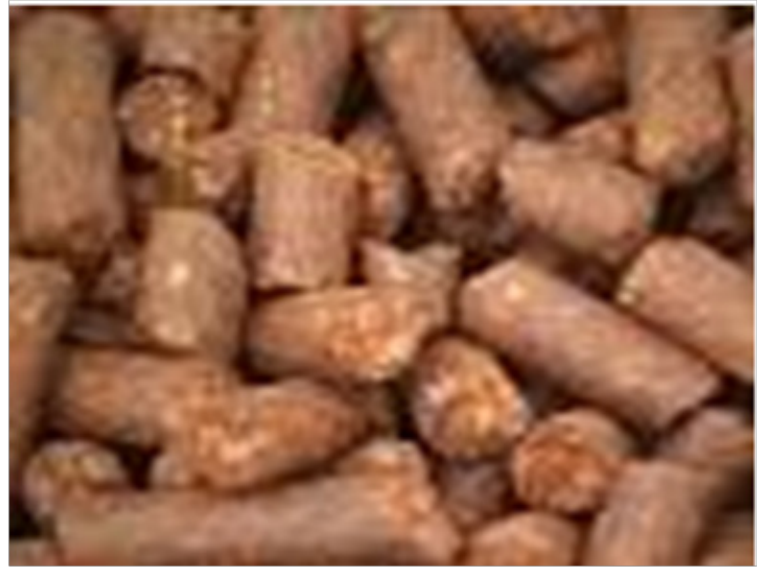

Figure 6 Pellets dried citrus molasses.

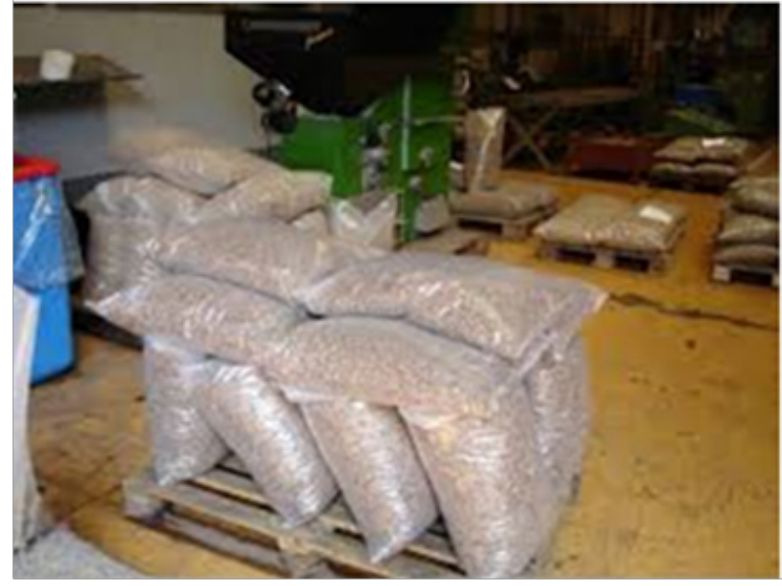

Figure 7 Belles dried citrus molasses in bags.

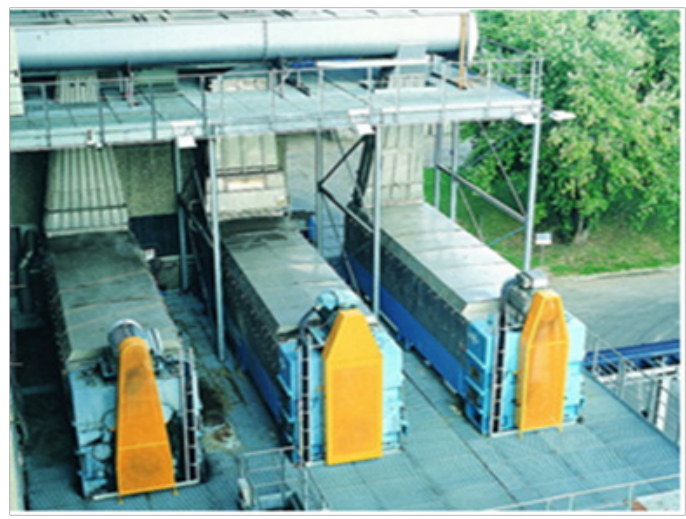

Figure 8 Machinery Dried Citrus Silage.

The use of $\mathrm{CP}$ for animal feeding was found to be an effective way to decrease waste output, and an exhaustive analysis should include an assessment of the environmental burdens associated to substitute feeds and of the associated costs of other methods of CP disposal. DCP is considered as an energy concentrate feed and a cereal substitute for ruminants. It has high fiber content (about $20 \% \mathrm{DM}$ of NDF) and contains large amounts (10-40\% DM) of highly DCP substances and water soluble sugars. It is also rich in calcium $(1-2 \% \mathrm{DM})$ due to the lime added in the drying process, which may triple the original calcium content. Its $\mathrm{CP}$ content is low (about $5-10 \% \mathrm{DM}$ ) as are $\mathrm{EE}$ (about $2 \% \mathrm{DM}$ ) and $\mathrm{P}$ (about $0.1 \% \% \mathrm{DM}$ ). Citrus pulp with citrus molasses added has higher sugar content and less fiber than citrus pulp without molasses. The high fiber content makes it essentially a feed for ruminants that can easily digest fiber (Figure 9) (Figure 10). ${ }^{12}$

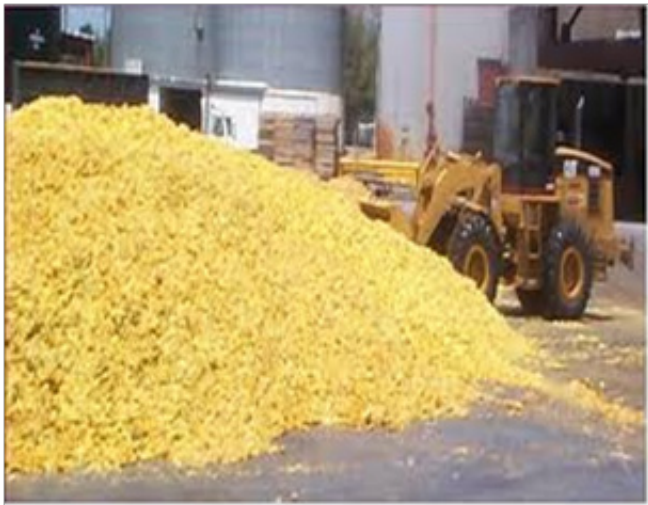

Figure 9 Citrus-peel wastes.

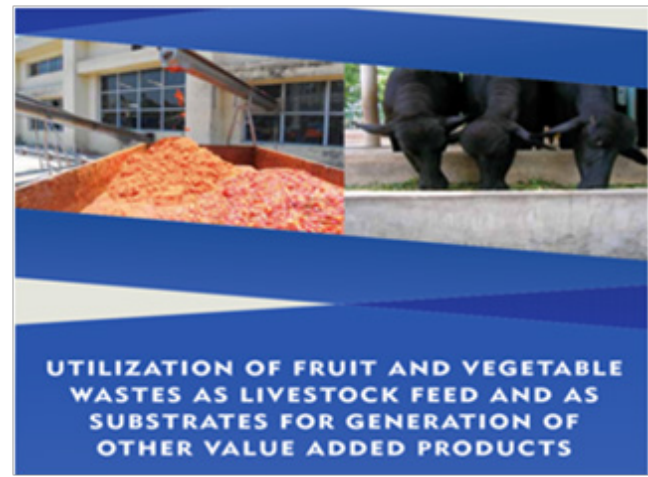

Figure 10 Utilization of fruits wastes as livestock feed. 
Nutrient composition of citrus by-products: Most citrus BPF have been assigned a unique international feed number and the chemical composition of various citrus BPF from several sources is summarized in Tables 2-4. The composition of citrus fruit is affected by growing conditions, maturity, rootstock, variety and climate. The nutrient content of citrus by-products is also influenced by the source of the fruit and method of processing. The nutrient content of citrus BPF is influenced also by factors that include the source of the fruit and type of processing..$^{17}$ The nutritional value of citrus pulp is high owing to its high content of readily fermentable carbohydrates. The protein content is modest, and of low digestibility and biological value ${ }^{18}$ because citrus pulp has high moisture content ( $80 \%)$ and it is bulky and therefore, it is difficult to store or transport it. It is rich in readily fermentable substrates such as sugars, non-starch polysaccharides and organic acids but poor in nitrogen. These characteristics make $\mathrm{CP}$ a suitable by-product to ensile with high DM cereal-crop residues such as wheat straw. ${ }^{19}$

Table 2 Average chemical composition of citrus pulp. ${ }^{20}$

\begin{tabular}{lllll}
\hline Main analysis & Units & Min & Max & X \pm SD \\
\hline DM & \% as fed & 86.5 & 92.6 & $89.6 \pm 1$ \\
CP & \% DM & 5.9 & 9.3 & $7.0 \pm 0.6$ \\
CF & \% DM & 10.9 & 16.1 & $13.5 \pm 0.8$ \\
NDF & \% DM & 16.3 & 23.7 & $21.1 \pm 1.6$ \\
ADF & \% DM & 13.8 & 18.9 & $15.4 \pm 1.1$ \\
Lignin & \% DM & 1 & 9 & $2.7 \pm 1.8$ \\
Ether Extract & \% DM & 1.5 & 3.9 & $2.4 \pm 0.6$ \\
Ash & \% DM & 5.5 & 8.6 & $6.9 \pm 0.5$ \\
Starch & \% DM & 1.8 & 12.4 & $7.5 \pm 3.1$ \\
Total Sugars & \% DM & 17.2 & 35.2 & $24.5 \pm 3.9$ \\
Gross Energy & MJ/kg DM & 17.1 & 18.2 & $17.3 \pm 0.3$ \\
\hline
\end{tabular}

Table 3 Minerals analysis of dried citrus pulp according to adas. ${ }^{21}$

\begin{tabular}{lllll}
\hline \multirow{2}{*}{$\begin{array}{l}\text { Chemical } \\
\text { composition }\end{array}$} & Feed name & & & \\
\cline { 2 - 5 } & Citrus pulp & CP dried & CP silage & Molasses \\
\hline DM & 18.3 & 90 & 20 & 65 \\
TDN & 82.5 & 77 & & \\
CP & 6.6 & 6.9 & 7.3 & 10.9 \\
EE & 3.3 & 3.8 & 10.4 & 3 \\
CF & 12.6 & 14 & & \\
ADF & 16 & 23 & 20 & 0 \\
Ca & 7.7 & 2.07 & 2.04 & 2 \\
P & 0.13 & 1.3 & 1.5 & 1.4 \\
NE & 7.91 & 7.36 & 8.03 & 7.36 \\
\hline
\end{tabular}

Table 4 Analysis of dried cp, cp silage and molasses according to adas. ${ }^{21}$

\begin{tabular}{lllll}
\hline Minerals & Units & Min & Max & X \pm SD \\
\hline Calcium & g/kg DM & 13 & 22.4 & $17.0 \pm 2.3$ \\
Phosphorus & g/kg DM & 0.7 & 1.5 & $1.0 \pm 0.2$ \\
Potassium & g/kg DM & 6.8 & 11.6 & $9.3 \pm 1.3$ \\
Sodium & g/kg DM & 0.3 & 4 & $1.2 \pm 1.3$ \\
Magnesium & g/kg DM & 1 & 2.1 & $1.3 \pm 0.4$ \\
Manganese & $\mathrm{mg} / \mathrm{kg} \mathrm{DM}$ & 5 & 14 & $8.0 \pm 3.0$ \\
Zinc & $\mathrm{mg} / \mathrm{kg} \mathrm{DM}$ & 6 & 57 & $14.0 \pm 14$ \\
Copper & $\mathrm{mg} / \mathrm{kg} \mathrm{DM}$ & 3 & 6 & $4.5 \pm 1.0$ \\
Iron & $\mathrm{mg} / \mathrm{kg} \mathrm{DM}$ & 46 & 144 & $80.0 \pm 32$ \\
\hline
\end{tabular}

Energy value and digestibility: Citrus pulp contains a variety of energy substrates for ruminal microbes, including both soluble carbohydrates and a readily digestible NDF fraction. CP has been previously used as a high energy feed in ration for supporting growth and lactation of cattle. ${ }^{22}$ A large number of the citrus by-products are suitable for inclusion in ruminant diets because of the ability of ruminants to ferment high fiber feeds in the rumen. ${ }^{11} \mathrm{CP}$ can be used in animal feeding either fresh or after ensiled or dehydrated. ${ }^{23}$ Due to its relatively high digestibility of organic matter disappearance (OMD) in the $85-90 \%$ range and energy value (ME about $2900 \mathrm{kcal} / \mathrm{kg} \mathrm{DM}$, $85-90 \%$ that of maize and comparable to barley ME), CP is used as a cereal substitute in concentrate diets. ${ }^{8}$ Unlike cereals, its energy is not based on starch but on soluble carbohydrates and digestible fiber. Citrus pectin are easily and extensively degraded, producing acetic acid, which is less likely than lactic acid to cause a $\mathrm{pH}$ drop and result in acidosis. Due to its high fiber content, the long rumination of $\mathrm{CP}$ produces large quantities of saliva that has a buffering effect on rumen $\mathrm{pH}$. $\mathrm{CP}$ is therefore considered as a safer feed than cereals for animals fed high-concentrate, low-roughage diets in high yielding dairy cows. ${ }^{16}$ In rations containing low digestibility forages (hay or straw) or based on roughages such as maize silage or sorghum silage, $\mathrm{CP}$ seems to have a positive effect on fiber digestibility, perhaps due to a longer rumen retention time. ${ }^{12}$

Important consideration when using citrus by products in animal feeding: The digestibility of the protein of $\mathrm{CP}$ is low and variable (from $37 \%$ to $70 \%$ ) and including large amounts of CP in diets containing protein-rich forages may cause a general decrease in protein digestibility. Its low soluble nitrogen content may result in a decrease in rumen ammonia. Supplementation with urea or ammonia can be a valuable strategy, as CP contains highly ferments carbohydrates that may promote a more efficient $\mathrm{N}$ utilization by rumen bacteria. ${ }^{24}$ However, true protein sources can be more efficient. Due to the low phosphorus content and to the Ca: P imbalance, phosphorus supplementation is an important consideration for balanced diets containing CP. As CP has a low content of vitamin A, green leafy roughage is an important ingredient in rations with high levels of CP. ${ }^{12}$

Nutrient digestibility of citrus by-products: When citrus BPF substituted for starchy feeds, DM and OM digestibility coefficients tend to remain unaffected, while CP digestibility decreases, and NDF and ADF digestibility coefficients increase ${ }^{25}$ Citrus BPF improve 
utilization of dietary fibrous fractions, possibly due to positive effects on rumen micro flora. Moreover, when straw is used as the basal feed for ruminants, the diet is improved by offering citrus BPF to correct nutrient deficiencies of the straw and to increase the digestion of its nutrients. ${ }^{26}$ Supplementation with increasing amounts of pelted CP tended to result in a linear increase in digestibility of total diet DM and $\mathrm{OM}$ and suggest that high levels of $\mathrm{CP}$ to beef cattle can lower forage intake, but increase total energy intake. High levels of CP supplementation could be beneficial in combination with forages high in rumen degradable protein (Table 5) (Table 6). ${ }^{26-28}$

Table 5 Chemical composition of citrus pulp as fresh and dry forms. ${ }^{27}$

\begin{tabular}{lll}
\hline $\begin{array}{ll}\text { Chemical } \\
\text { Composition (\%) }\end{array}$ & $\begin{array}{l}\text { Citrus pulp in } \\
\text { fresh form }\end{array}$ & $\begin{array}{l}\text { Citrus pulp in } \\
\text { dry form }\end{array}$ \\
\hline Dry matter & 85.36 & 100 \\
Crude protein & 8.25 & 9.66 \\
Crude fat & 3.78 & 4.43 \\
Crude fiber & 10.82 & 12.68 \\
Crude ash & 3.17 & 3.71 \\
NFE & 59.34 & 69,32 \\
TDN (cattle) & 76.15 & 89.21
\end{tabular}

Table 6 Nutritive values analysis of dried citrus pulp in ruminants. ${ }^{21}$

\begin{tabular}{lllll}
\hline Ruminant nutritive values & Unit & Min & Max & X \\
\hline OM Digestibility & $\%$ & 83 & 91 & 88 \\
Energy Digestibility & $\%$ & 79 & 89 & 83.9 \\
DE & MJ/ kg DM & 13.7 & 15.9 & 14.5 \\
ME & MJ/ kg DM & 11.4 & 13.2 & 12.1 \\
Nitrogen Digestibility & $\%$ & 44 & 67.6 & 57.6 \\
\hline
\end{tabular}

Effects of citrus by-products on growing ruminants: The effects of type of feedstuffs under both mild and hot periods of the year on crossbred calves were studied by Habeeb et al. ${ }^{3}$ The first group fed the concentrate feed mixture (Traditional ration) while the second group fed the waste products from food industries (untraditional ration). The mixture by-products from food industries consisted of $20 \%$ citrus pulp, $20 \%$ potato wastewater pea pods $30 \%$ and tomato pulp $30 \%$. The chemical composition of the two types of feedstuffs is in Table 7. The results indicated that there were insignificant differences in DBWG of crossing calves fed traditional or untraditional rations, while Untraditional ration decreased significantly activities of GPT and $\gamma \mathrm{GT}$ enzymes and increased significantly globulin concentration. The authors concluded that the untraditional feeding was better than traditional ration, especially, during summer period and revealed that ration increase the appetite of calves as a result to their different contents and high level of water (Table 8). ${ }^{30}$

Table 7 Components and chemical composition of untraditional ration (wastes mixture) and traditional ration (concentrate feed mixture). ${ }^{3}$

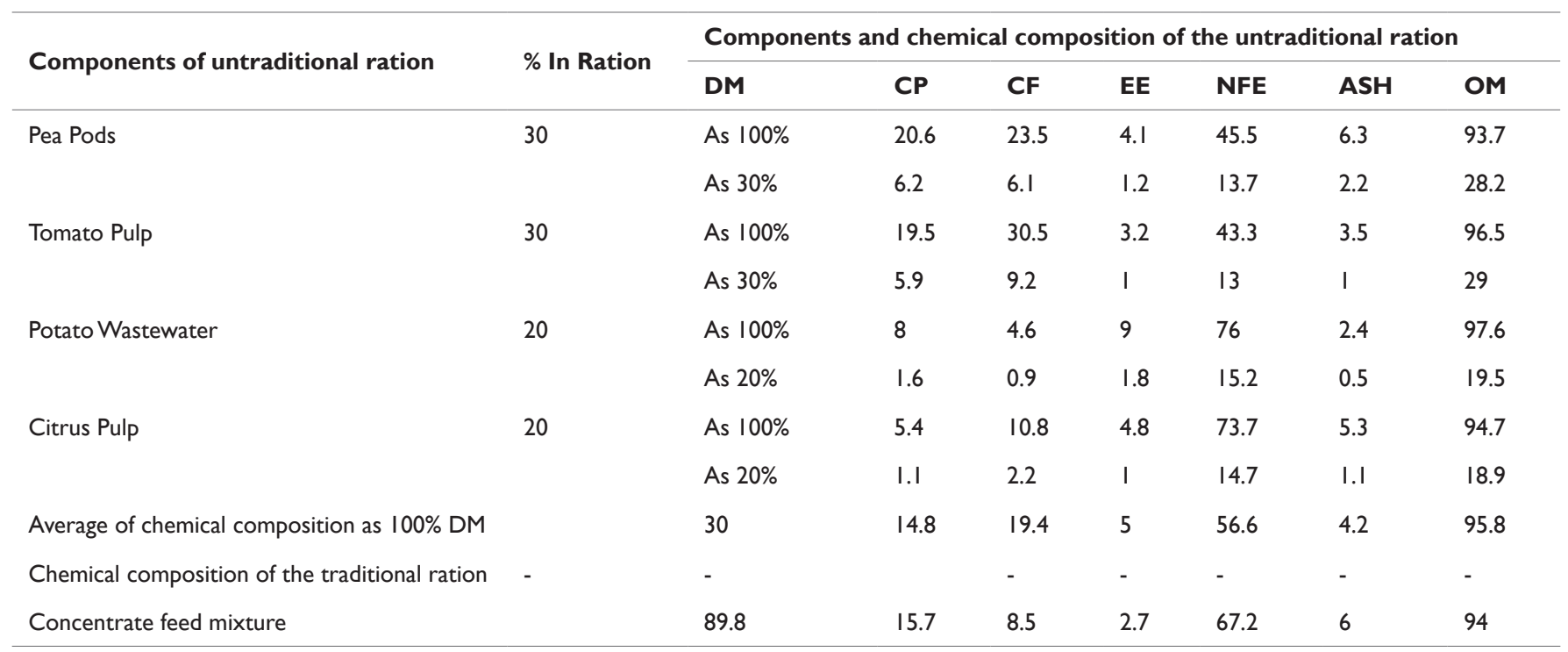

Table 8 Daily body weight gain (dbwg) of crossing calves as affected by feeding type. ${ }^{3}$

\begin{tabular}{llll}
\hline \multirow{2}{*}{ DBWG, $g$} & \multicolumn{2}{l}{ Feeding type } & \\
\cline { 2 - 4 } & Traditional & Untraditional & Sig. $(\mathbf{p} \leq)$ \\
\hline $1^{\text {st }}$ month & $648 \pm 20$ & $682 \pm 20$ & 0.33 \\
$2^{\text {nd }}$ month & $762 \pm 30$ & $704 \pm 30$ & 0.42 \\
$3^{\text {rd }}$ month & $790 \pm 30$ & $789 \pm 30$ & -- \\
\hline
\end{tabular}

Average DBWG throughout the feeding trials were 841,810 and $741 \mathrm{~g}$ for the buffalo calves fed rations, in calves fed on CFM and hay, in calves fed citrus wastes and pea pods and hay and calves fed artichoke wastes and pea pods and hay, respectively. ${ }^{31}$ The DBWG improved with replacement of yellow corn by citrus by-product and improved feed efficiency and decreased daily feeding cost, consequently improved relative economical efficiency. ${ }^{32}$ Half substitution of corn grain by dried orange pulp concentrates fed to Friesian heifers, from 6 to 18 month, did not negatively affect body weight. ${ }^{25}$ No significant differences in gain for steers fed citrus pulp, corn feed meal and ground snapped corn when combined with adequate protein and other essential nutrients in a ration for young growing steers. ${ }^{33}$

DCP is also a valuable feed for beef and growing cattle and can partly replace energy sources. It can be safely included in rations at 
$20-30 \%$ of the $\mathrm{DM},{ }^{16}$ but higher values are feasible. It was possible to include up to $40 \%$ DCP in the diets of fattening cattle without altering animal health. Up to $55 \%$ dried pulp in the diets of young bulls (replacing $86 \%$ of maize grain) did not affect live weight gain and carcass yields. On beef cattle fed low-quality stargrass, increasing amounts of DCP (up to $2.5 \mathrm{~kg}$ / day /animal (as fed), $30 \%$ of the diet $\mathrm{DM})$ led to lower forage intake but higher energy intake. CP at $30 \%$ appears to be advisable in rations for calves over two months old, but because of acceptability factors not for younger ones. A $45 \%$ inclusion rate in calf rations was also reported.

Chen et al. ${ }^{29}$ evaluated Citrus condensed molasses soluble (CCMS) as an energy source for ruminants. In two feeding studies with steers, CCMS was added to the DCP and corn grain based diets in the first study at $0,70,140$, and $210 \mathrm{~g} / \mathrm{kg}$ to replace corn or DCP and, in the second, at $0,25,50$, and $100 \mathrm{~g} / \mathrm{kg}$ to replace sugarcane molasses. The BW gain, FCR and carcass characteristics did not differ among treatments. In another study with lambs, CCMS was added to the diets at 0,100 and $200 \mathrm{~g} / \mathrm{kg}$ DM to replace corn grain or SBM, and BW gain was lower for the high CCMS diet, but DM intake was similar among treatments. Overall, results suggest that substitution of corn and wheat grains with citrus BPF results in equal growth of ruminants. Effects of orange pulp silage on growth and carcass characteristics of lambs were reported by Scerra et al. ${ }^{31}$ To limit ensiling losses due to the high moisture content of the citrus pulp, it was ensiled with chopped wheat straw in a ratio 80:20 DM. Twenty lambs received one of two diets, a diet of oat hay plus concentrate and a diet of citrus pulp silage plus concentrate. The authors concluded that use of citrus pulp silage was economically advantageous to produce lambs with acceptable carcass and meat quality characteristics (Table 9).

Table 9 Effect of dried citrus pulp on feed intake and growth and carcass performance of fattening cattle. ${ }^{28}$

\begin{tabular}{|c|c|c|c|c|}
\hline Feed stuffs & Citrus Level & DBWG (G/D) & FC & Carcass Yield \\
\hline \multirow{2}{*}{ Barley- DCP concentrate $(g / \mathrm{kg})$, Male calves } & $820-0$ & 1090 & 6.3 & 57.9 \\
\hline & $200-600$ & 1070 & 6.5 & 56.5 \\
\hline \multirow{4}{*}{ DCP concentrate $(\mathrm{g} / \mathrm{kg})$ Male lambs } & 0 & 259 & 3.6 & 55.8 \\
\hline & 150 & 272 & 3.5 & 53.3 \\
\hline & 300 & 256 & 3.6 & 54.7 \\
\hline & 450 & 127 & 5.5 & 53.9 \\
\hline \multirow{4}{*}{ DCP concentrate $(\mathrm{g} / \mathrm{kg})$ Female lambs } & 0 & 188 & 4.5 & 56.5 \\
\hline & 150 & 199 & 4.3 & 56.7 \\
\hline & 300 & $|7|$ & 4.9 & 54.3 \\
\hline & 450 & 143 & 5.7 & 56.6 \\
\hline \multirow{2}{*}{ Corn-DCP Total mixed ration (TMR) (g/kg), Steers } & $710-0$ & 1170 & 7.81 & 58.1 \\
\hline & $355-400$ & 1060 & 7.83 & 57.5 \\
\hline \multirow{2}{*}{ Corn-DCPTMR (g/kg), Steers } & $710-0$ & 1020 & 10.5 & - \\
\hline & $355-400$ & 1060 & 7.83 & 57.5 \\
\hline \multirow{4}{*}{ Citrus condensed molasses soluble (CCMS) TMR (g/kg DM), Steers } & 0 & 1180 & 7.4 & 61.6 \\
\hline & 31.5 & 1080 & 8.7 & 60.7 \\
\hline & 63 & 1030 & 8.7 & 60.1 \\
\hline & 94.5 & 1110 & 8.6 & 61.2 \\
\hline \multirow{3}{*}{ Dried orange pulp (DOP) concentrate $(\mathrm{g} / \mathrm{kg}$ ), Bulls } & 0 & 1211 & 5.4 & 53.2 \\
\hline & 50 & 1120 & 6.4 & 55.2 \\
\hline & 500 & 1098 & 6.5 & 54.3 \\
\hline
\end{tabular}

Effects of citrus by-products on physiological body functions: Fed untraditional ration as compared to traditional ration in crossing calves decreased albumin and increased globulin concentrations while total protein values were not affected due to type of feeding and concluded that untraditional ration increased the immunity, especially, under hot summer season (Table10). ${ }^{3}$ In addition, fed untraditional ration to crossing calves decreased GOT and $\gamma$ GT activities and attributed that untraditional ration may be decrease the heat load on animals during hot summer season and concluded that using agro-industrial by-0roducts mixtures as feed components for ruminants is reasonable and is not expected to change the enzymatic activity in the ruminants. Both urea-N and glucose concentrations in crossing calves were lower significantly in calves fed untraditional ration as compared to traditional ration and the percentages decrease values were 30.0 and 16.0 , respectively.

Blood plasma glucose slightly increased in group fed 50\% concentrate feed mixture $+50 \%$ vegetable fruit market wastes silage treated with lactic acid bacteria; and group fed $50 \%$ concentrate feed mixture $+50 \%$ vegetable and fruit market wastes with silage treated formic acid compared to the group which was fed concentrate feed 
mixture and the roughage source was Darawa. ${ }^{34}$ SGOT and SGPT were not significantly different from control rations and agro-industrial by products mixtures. ${ }^{35}$ No significant differences in blood concentration of total protein, albumin and globulin in cows fed on DCP than in those fed on the control diet. ${ }^{36}$ Total lipids, total cholesterol and triglycerides concentrations in crossing calves were higher significantly in group intake traditional ration than that fed the untraditional (Table 11). ${ }^{3}$

Table 10 Effect of citrus by-product levels on performance of growing ruminants. ${ }^{8-29}$

\begin{tabular}{|c|c|c|c|c|c|c|}
\hline \multirow{2}{*}{$\begin{array}{l}\text { Growth } \\
\text { Performance }\end{array}$} & \multicolumn{3}{|c|}{$\begin{array}{l}0,20 \text { and } 40 \% \text { concentrates were replaced with citrus } \\
\text { pulp silage }\end{array}$} & \multicolumn{3}{|c|}{$\begin{array}{l}0,20,40 \% \text { wheat bran in } \\
\text { concentrates were replaced with citrus pulp silage }\end{array}$} \\
\hline & Control & $20 \%$ & $40 \%$ & Control & $20 \%$ & $40 \%$ \\
\hline Initial Weight, Kg & 210 & 197 & 204 & 222 & 217 & 217 \\
\hline Final Weight, Kg & 281 & 264 & 252 & 266 & 269 & 252 \\
\hline Weight Gain, Kg & 71 & 67 & 48 & 44 & 52 & 35 \\
\hline Gain/Concentrate & 0.78 & 0.71 & 0.54 & 0.75 & 0.88 & 0.6 \\
\hline Daily Intake, Kg As DM Basis & 5.07 & 5.1 & 5.66 & 3.84 & 5.72 & 8.53 \\
\hline Silage Intake, $\mathrm{Kg}$ & 4.34 & 3.44 & 4.34 & 7.35 & 7.36 & 7.28 \\
\hline Hay Intake, $\mathrm{Kg}$ & 1.91 & 2.12 & 2.08 & 0.99 & 0.99 & 0.98 \\
\hline
\end{tabular}

Table I I Effect of untraditional ration on physiological performance and animal body functions in crossing calves. ${ }^{3}$

\begin{tabular}{|c|c|c|c|}
\hline \multirow{2}{*}{$\begin{array}{l}\text { Physiological } \\
\text { functions }\end{array}$} & \multicolumn{3}{|l|}{ Feeding type } \\
\hline & Traditional & Untraditional & Sig.(P) \\
\hline Total Proteins (g/dl) & 6.090 .8 & 6.390 .8 & 0.23 \\
\hline Albumin $(g / d l)$ & 3.980 .002 & 3.750 .02 & 0.05 \\
\hline Globulin $(g / d l)$ & 2.110 .08 & 2.540 .08 & 0.001 \\
\hline GOT (U/ml) & $64.46 \pm 3.8$ & $56.64 \pm 4.8$ & 0.01 \\
\hline GPT (U/ml) & $32.6 I \pm 2.2$ & $32.38 \pm 2.3$ & 0.67 \\
\hline$\gamma \mathrm{GT}(\mathrm{U} / \mathrm{l})$ & $14.3 \pm 0.50$ & II $.50 \pm 0.52$ & 0.001 \\
\hline Urea-N (mg/dl) & $35.54 \pm 1.6$ & $24.94 \pm 1.7$ & 0.001 \\
\hline Creatinine (mg/dl) & $1.83 \pm 0.06$ & $1.81 \pm 0.06$ & 0.54 \\
\hline Glucose (mg/dl) & $91.88 \pm 4.0$ & $77.50 \pm 4.0$ & 0.02 \\
\hline Total lipids (mg/dl) & $512.3 \pm 13$ & $461.6 \pm 12.0$ & 0.01 \\
\hline Cholesterol mg/dl) & $93.09 \pm 3.8$ & $80.86 \pm 2.8$ & 0.01 \\
\hline Triglycerides (mg/dl) & $81.42 \pm 2.9$ & $69.72 \pm 1.9$ & 0.01 \\
\hline $\mathrm{T} 4(\mathrm{nmo} / \mathrm{l})$ & $85.67 \pm 3.2$ & $86.11 \pm 3.2$ & 0.87 \\
\hline $\mathrm{T} 3(\mathrm{nmo} / \mathrm{l})$ & $2.10 \pm 0.02$ & $2.07 \pm 0.04$ & 0.55 \\
\hline Cortisol (ng/dl) & $14.2 \pm 0.13$ & $13.9 \pm 0.12$ & 0.76 \\
\hline Parathormone (pg/ml) & $15.9 \pm 0.45$ & $16.35 \pm 0.54$ & 0.57 \\
\hline
\end{tabular}

Plasma cholesterol recorded a significant increase in the group that fed $50 \%$ concentrate feed mixture $+50 \%$ vegetable fruit market wastes silage treated with lactic acid bacteria and group was fed $50 \%$ concentrate feed mixture $+50 \%$ vegetable and fruit market wastes with silage treated formic acid compared to the group which was fed concentrate feed mixture and the roughage source was Darawa. ${ }^{34}$ No significant differences were observed in blood concentration of triglycerides, while serum concentration of cholesterol was higher in cows fed on dried citrus pulp than in those fed on the control diet. ${ }^{36}$ No significant differences in concentrations of T4, T3, cortisol and parathormone hormones due to type of rations. ${ }^{3}$ The same authors concluded that daily body weight gain of crossing calves was not affected by feeding the untraditional ration and concentrations of most blood components were in normal range indicating the importance of untraditional feeding, especially, during hot summer season particularly that ration without any addition cost except their trance from Factories to Farms.

Effects of Citrus pulp on lactating ruminants: Citrus pulp is a valuable feedstuff for dairy cows. The extensive acetic acid production in the rumen allows to maintain milk yield and milk fat content when forage is scarce (low fiber diet) or when high energy is required (as cereal replacer, for example). A level of $40 \%$ of the total ration has been considered feasible. However, inclusion rates lower than 20\% (diet DM) are recommended and higher levels may alter negatively DM intake, milk parameters and diet digestibility. DCP, included at $20 \% \mathrm{DM}$, as a concentrate replacer in a $50-60 \%$ maize or sorghum silage-based diet did not change DM intake, milk yield or milk protein content. ${ }^{12}$ Below $20 \%$, neither rumen parameters nor digestibility are altered. Between $20 \%$ and $24 \%$ inclusion in mixed dairy rations, ruminal parameters remain unaltered but milk yield and milk protein content may be lower while milk fat content remains equal or increased. Beyond $24 \%$ of the total diet, DCP decreased total DM intake, and total dry and organic matter digestibility (Table 12). ${ }^{36}$

Partial or total substitution of corn or barley grain by dried orange pulp (DOP) or dried lemon pulp (DLP) in the concentrates fed to Friesian dairy cattle had no negative effects on milk production or the fat content or flavour of milk Van Horn et al. ${ }^{35-37}$ studied effects of high corn grain $(80 \mathrm{~g} / \mathrm{kg}$ DCP $)$ and high DCP $(431 \mathrm{~g} / \mathrm{kg}$ DCP) TMR on lactating dairy cow performance and milk composition and found that feed intake, milk yield and milk protein content were similar among treatments. The same authors found that in high DCP versus high corn TMR, milk fat content was $42.2 \mathrm{~g} / \mathrm{kg}$ versus $35.4 \mathrm{~g} / \mathrm{kg}$, and milk SNF content was $90.3 \mathrm{~g} / \mathrm{kg}$ versus $88.4 \mathrm{~g} / \mathrm{kg}$. Solomon et al. ${ }^{38}$ also studied effects of the TMR with high starch (corn grain (22. $\mathrm{kg} \mathrm{DM} / \mathrm{cow} / \mathrm{d})$, which contained corn grain $(204 \mathrm{~g} / \mathrm{kg} \mathrm{DM}))$ or high pectin (DCP) TMR (20.8kg DM/cow/d), which contained corn grain $(93 \mathrm{~g} / \mathrm{kg} \mathrm{DM})$ and DCP $(207 \mathrm{~g} / \mathrm{kg} \mathrm{DM})$ on lactating Holstein dairy cow performance and milk composition. The authors found that milk yield and fat 
content was not affected due to treatment but milk protein content was higher in the high starch TMR. Leiva et al. ${ }^{39}$ also evaluated the performance of dairy cattle fed DCP or corn products and found that DM, CP and NDF intakes, as well as milk yield, milk fat content and yield, and milk protein yield were not affected by diet. Volanis et al. ${ }^{40}$

Table 12 Effect of citrus by-products on performance of lactating ruminants. ${ }^{8}$ evaluated effects of feeding ensiled sliced oranges to lactating dairy sheep. Three kilograms (79.5\%) of sliced orange silage mixture were offered daily to the animals in replacement for part of the maize grain/ soybean meal/oat hay ration fed to the control group.

\begin{tabular}{|c|c|c|c|c|c|c|}
\hline Feedstuffs & Citrus level & $D M(g / d)$ & Milk Yield (G/D) & Fat (g/kg) & Protein $(\mathrm{G} / \mathrm{Kg})$ & Lactose (G/Kg) \\
\hline \multirow{2}{*}{$\begin{array}{l}\text { DCPTMR } \\
(\mathrm{g} / \mathrm{kg})\end{array}$} & 80 & 1870 & 18200 & 35.4 & 34 & 8 \\
\hline & 431 & 1870 & 17900 & 42.2 & 34 & 6 \\
\hline \multirow{2}{*}{$\begin{array}{l}\text { DCPTMR } \\
\text { (g/kg DM) }\end{array}$} & 0 & 1860 & 23100 & 41.2 & 32 & 2 \\
\hline & 200 & 1870 & 23600 & 44.8 & 32 & 2 \\
\hline \multirow{2}{*}{$\begin{array}{l}\text { Corn-DCPTMR } \\
(\mathrm{g} / \mathrm{kg} \text { DM) }\end{array}$} & $96-204$ & 2200 & 38300 & 33.3 & 28.7 & - \\
\hline & $93-207$ & 2080 & 38200 & 33.3 & 28.2 & - \\
\hline \multirow{2}{*}{$\begin{array}{l}\text { Corn -DCPTMR } \\
(\mathrm{g} / \mathrm{kg} \text { DM) }\end{array}$} & $22-253$ & 2140 & 32800 & 34.3 & 28.3 & - \\
\hline & $236-37$ & 2090 & 31300 & 35.4 & 27 & - \\
\hline \multirow{2}{*}{$\begin{array}{l}\text { Corn meal-DCPTMR } \\
\text { (g/kg DM) }\end{array}$} & $195-96$ & - & 31800 & 32.7 & 30 & - \\
\hline & $92-205$ & - & 27900 & 34.5 & 30 & - \\
\hline
\end{tabular}

The authors found that milk yield was $12 \%$ higher for controls and ewes fed orange silage had a $16 \%$ higher fat content in milk and showed that the inclusion of sliced oranges decreased milk yield and milk protein concentration, probably due to a reduced microbial protein synthesis and flow to the intestine, and increased milk fat concentration, probably due to a concentration effect. Todaro et al. ${ }^{41}$ reported that the supplementation of wet lemon (Citrus lirnon L.) pulp to late-lactation ewes grazing on natural pastures positively influenced milk yield $(0.89 \mathrm{~kg} / \mathrm{d}$ versus $0.72 \mathrm{~kg} / \mathrm{d})$, decreased milk protein content $(52 \mathrm{~g} / \mathrm{L}$ versus $55.7 \mathrm{~g} / \mathrm{L})$ and did not modify milk fat concentration, nitrogen fractions or milk coagulation properties compared to ewes which did not receive the supplement. Bampidis \& Robinson ${ }^{8}$ reported that the inclusion of DCP up to level of $300 \mathrm{~g} / \mathrm{kg}$ of concentrate DM (about $110 \mathrm{~g} / \mathrm{kg}$ of dietary DM) as a replacement for grains, soybean meal, and wheat middlings in the diet of low productive dairy ewe did not affect milk yield or milk fat, protein, or lactose concentrations but modified milk fatty acids profile. Vasta et al. ${ }^{42}$ reported that $\mathrm{CP}$ can be used wet, dried or pelletted in the diet of dairy animals and overall, results suggest that substitution of corn grain, as well as several other high starch feeds with citrus BPF results in equal milk yield and composition in lactating ruminants. ${ }^{43}$

\section{Conclusion}

The main citrus BPF fed to ruminants are fresh citrus pulp, citrus silage, dried citrus pulp, citrus meal and fines, citrus molasses, citrus peel liquor, and citrus activated sludge. Supplementation of forages with citrus BPF that are rich in pectin or highly degradable NDF usually has a less negative effect on the rumen ecosystem and thus on cellulolysis, than supplementation with starch or sugar rich feeds. Citrus BPF contain a variety of energy substrates for ruminal microbes, including both soluble carbohydrates and rapidly digested NDF. When citrus BPF substituted for starchy feeds, DM and OM digestibility coefficients tend to remain unaffected, $\mathrm{CP}$ digestibility decreases and NDF and ADF digestibility coefficients increase. Citrus BPF improve the utilization of other dietary NDF, possibly due to positive effects on rumen microflora. Moreover, when straw is used as the basal feed for ruminants, their diet is improved by feeding citrus BPF to correct nutrient deficiencies of the straw and to increase digestibility of its nutrients. Citrus BPF as high pectin energy sources, when included in diets for ruminants, tends to increase the molar proportion of acetic acid and decrease the molar proportion of propionic acid, resulting in an increased acetate/propionate ratio. Citrus BPF can be used as a high energy feed in rations that support growth and lactation in ruminants.

\section{Acknowledgements}

None.

\section{Conflict of interest}

Author declares that there is no conflict of interest.

\section{References}

1. Baraghit GA, BM Ahmed, MA El Mahy. Digestibility, nutritive value and rumen fermentation of rice straw and sugarcane bagasse treated with a commercial bacterial culture. Egyptian J Nutrition and Feeds. 2009;12(3):511-522.

2. Zaza GHM. Effect of incorporation of biologically treated sugar beet pulp as non-conventional feedstuffs in the diets of growing rabbits. The 4th Inter. Conf. on Rabbits Production in hot climates. Sharm El-Sheikh, Egypt; 2005.

3. Habeeb AAM, AE Gad, AA EL Tarabany. Effect of two climatic conditions and types of feeding on body weight gain and some physiological and biochemical parameters in crossing calves. Zagazig vet J. 2011;39(3):34-48.

4. Nour AM. Agricultural industry wastes in animal nutrition. 1st National Conf on Role of scientific research and Technology. Cairo, Egypt; 1988.

5. USDA-FAS. Citrus: World Markets and Trade. Citrus Update, Foreign Agriculture Service-USDA. USA; 2010. p. 1-9.

6. Mirzaei AA, NM Sis. Nutritive Values of Some Agro-Industrial By-products for Ruminants- A Review. World Journal of Zoology. 2008;3(2):40-46.

7. Heather A Duoss Jennings, Ty B Schmidt, Todd R Callaway, et al. Effect of Citrus Byproducts on Survival of O157:H7 and Non-O157 Escherichia coli Serogroups within In Vitro Bovine Ruminal Microbial Fermentations. International Journal of Microbiology. 2013;1-5. 
8. Bampidis VA, PH Robinson. Citrus by-products as ruminant feeds: A review. Animal Feed Science and Technology. 2006;128(4):175-217.

9. Zaza AIA. Performance of Awassi Lambs fed citrus pulp and olive cake silage. Faculty of graduate studies at An Najah National University, Nablus, Palestine. 2008. p. 1-18.

10. Range Cattle Research and Education Center (RCREC). Citrus Pulp: New information for an old feed byproduct. University of Florida, IFAS, USA; 2009.

11. Grasser LA, JG Fadel, I Garnett, et al. Quantity and economic importance of nine selected by-products used in California dairy rations. J Dairy Sci. 1995;78(4):962-971.

12. Arthington JD, WE Kunkle, AM Martin. Citrus pulp for cattle. Vet Clin North Am Food Anim Pract. 2002;18(2):317-326.

13. Devendra C, Gohl BI. The chemical composition of Caribbean feeding stuffs. Trop Agric Trin. 1970;4:335-342.

14. Devendra C. Non-conventional feed resources and fibrous agricultura residues. Strategies for expanded utilization. International Development Research Council (IDRC), Ottawa, Canada and Indian Council of Agricultural research. New Delhi, India; 1988. p. 1-26.

15. Gohl BI. Ruminant nutrition: selected articles from the World Anima Review. Citrus by-products for animal feed. FAO Corporate Document Repository, Produced by Agiculture and Consumer Protection. Animal Nutrition. FAO, Rome, Italy; 2007.

16. Crawshaw R. Co-product feeds: animal feeds from the food and drinks industries, Nothingham University Press. J Science of Food \& Agriculture. 2004;83(4):362.

17. Ammerman CB, Henry PR. Citrus and vegetable products for ruminan animals. In: Proceedings of the Alternative Feeds for Dairy and Beef Cattle Symposium. St Louis, USA; 1991. p. 103-110.

18. Fegeros K, Zervas G, Stamouli S, et al. Nutritive value of dried citrus pulp and its effect on milk yield and milk composition of lactating ewes. J Dairy Sci. 1995;78(5):1116-1121.

19. Migwi PK, Gallagher JR, Van Barneveld RJ. The nutritive value of citrus pulp ensiled with wheat straw and poultry litter for sheep. Aust J Exp Agric. 2001;41:1143-1148.

20. Bath DL, JR Dunbar, JM king, et al. By-products and unusual feedstuffs in livestock rations. Western Regional Extension Publication No 39 USDA-ARS, Washington, USA; 1980.

21. ADAS. Dried citrus pulp. ADAS Nutrition Chemistry Feed Evaluation Unit. Technical Bulletin No92/8, 1992. p. 1-22.

22. Lanza M, A Priolo, L Biondi, et al. Replacement of cereal grains by orange pulp and carob pulp in faba bean-based diets fed to lambs: effects on growth performance and meat quality. Anim Res. 2001;50:21-30.

23. Bueno MS, E Ferrari, D Bianchini, et al. Effect of replacing corn with dehydrated citrus pulp in diets of growing kids. Small Rumin Res, 2002;46(2-3):179-185.

24. Rihani N. Valeur alimentaire ET utilization des sous-produits des agrumes en alimentation animale. Options Mediterraneennes, Serie Seminaires. 1991;16:113-117.

25. Lanza A. Dried citrus pulp in animal feeding. In: J Hollo, editor. Proceedings of the International Symposium on Food Industries and the Environment Budapest. Hungary, New York, USA; 1984. p. 189-198.

26. Villarreal M, RC Cochran, A Rojas Bourrillón, et al. Effect of supplementation with pelleted citrus pulp on digestibility and intake in beef cattle fed a tropical grass-based diet (Cynodon nlemfuensis). Animal Feed Science and Tech. 2006;125(1-2):163-173.
27. Jong Kyu Ha, SW Kim, WY Kim. Use of Agro-Industrial By-Products as Animal Feeds in Korea. Report of Food and Fertilizer Technology Center for Asian and Pacific Region. Korea; 2006.

28. Heuzé V, Tran G, Hassoun P. Citrus pulp, dried. Feedipedia. 2012.

29. Chen MC, Ammerman CB, Henry, PR, et al. Citrus condensed molasses soluble as an energy source for ruminants. J Anim Sci. 1981;53:253-259.

30. Scerra V, Caparra P, Foti F, Citrus pulp and wheat straw silage as an ingredient in lamb diets: effects on growth and carcass and meat quality. Small Rumin Res. 2001;40(1):51-56.

31. Lashin ME, EA Saad, HA Salama, et al. Use of citrus wastes, pea pods and artichoke as silage for feeding buffalo calves. Proc 5th Sci Conf Animal Nutrition. 1995;1:137-144.

32. Omer HAA, MA Tawila. Response of Baladi Goats to diets containing different levels of citrus by-product. Egyptian J Nutrition and Feeds. 2009;12(1):75-88

33. Peacock FM, WG Kirk. Comparative feeding value of dried citrus pulp, corn feed meal and ground snapped corn for fattening steers in dry lot. Animal Science Department, Florida Cooperative Extension Service, Institute of Food and Agricultural Science. University of Florida, USA; 2003.

34. Khattab MS. Preparation of silage from vegetable and fruits market wastes treated with some additives and its effect on the productive performance of lactating animals. Thesis Fac of Agric Ain-Shams University, Egypt; 2008.

35. El Sayed IM. Nutritive value evaluation of some crops, vegetable and fruit residues. M. Sc. Thesis, Fac of Agric, Cairo, Univ, Egypt; 1994

36. Belibasakis NG, Tsirgoyianni. Effects of dried citrus pulp on milk yield, milk composition and blood components of dairy cows. Animal Feed Science and Tech. 1996;60(1-2):87-92.

37. Van Horn HH, Marshall SP, Wilcox CJ, et al. Complete rations for dairy cattle. III. Evaluation of protein percent and quality, and citrus pulp-corn substitutions. J Dairy Sci. 1975;58(8):1101-1108.

38. Solomon R, Chase LE, Ben Ghedalia D, et al. The effect of nonstructural carbohydrate and addition of full fat extruded soybeans on the concentration of conjugated linoleic acid in the milk fat of dairy cows. $J$ Dairy Sci. 2000;83(6):1322-1329.

39. Leiva E, Hall MB, Van Horn HH. Performance of dairy cattle fed citrus pulp or corn products as sources of neutral detergent-soluble carbohydrates. J Dairy Sci. 2000;83(12):2866-2875.

40. Volanis M, Zoiopoulos P, Tzerakis K. Effects of feeding ensiled sliced oranges to lactating dairy sheep. Small Rum Res. 2004;53(1-2):15-21.

41. Todaro M, Cacciatore T, Ferrantelli M, et al. Influenza del pastazzo di limone sulle caratteristiche qualitative e quantitative del latte di pecora. In: Proc 6th Natl Congr SIPAOC. Siena, Italy; 2004. p. 331.

42. Vasta V, A Nudda, A Cannas, et al. Alternative feed resources and their effects on the quality of meat and milk from small ruminants. Review. Animal Feed Science and Technology. 2008;147(2):223-246.

43. Sinclai WB. The Biochemistry and Physiology of the Lemon and Other Citrus Fruits. Division of Agriculture and Natural Resources. University of California, Oakland, USA; 1984 